\title{
Enhancement of viability of radiosensitive (PBMC) and resistant (MDA-MB-231) clones in low-dose-rate cobalt-60 radiation therapy*
}

\author{
Aumento de viabilidade de clones radiossensivel (PBMC) e resistente (MDA-MB-231)
}

na cobaltoterapia em taxa de dose reduzida

\section{Patrícia Lima Falcão ${ }^{1}$, Bárbara Miranda Motta ${ }^{2}$, Fernanda Castro de Lima ${ }^{3}$, Celso Vieira Lima ${ }^{4}$, Tarcísio Passos Ribeiro Campos ${ }^{5}$}

Falcão PL, Motta BM, Lima FC, Lima CV, Campos TPR. Enhancement of viability of radiosensitive (PBMC) and resistant (MDA-MB-231) clones in lowdose-rate cobalt-60 radiation therapy. Radiol Bras. 2015 Mai/Jun;48(3):158-165.

Abstract Objective: In the present study, the authors investigated the in vitro behavior of radio-resistant breast adenocarcinoma (MDA-MB-231) cells line and radiosensitive peripheral blood mononuclear cells (PBMC), as a function of different radiation doses, dose rates and postirradiation time kinetics, with a view to the interest of clinical radiotherapy.

Materials and Methods: The cells were irradiated with Co-60, at 2 and 10 Gy and two different exposure rates, 339.56 cGy.min ${ }^{-1}$ and the other corresponding to one fourth of the standard dose rates, present over a 10-year period of cobalt therapy. Post-irradiation sampling was performed at pre-established kinetics of 24,48 and 72 hours. The optical density response in viability assay was evaluated and a morphological analysis was performed.

Results: Radiosensitive PBMC showed decrease in viability at $2 \mathrm{~Gy}$, and a more significant decrease at 10 Gy for both dose rates. MDAMB-231 cells presented viability decrease only at higher dose and dose rate. The results showed MDA-MB-231 clone expansion at low dose rate after 48-72 hours post-radiation.

Conclusion: Low dose rate shows a possible potential clinical impact involving decrease in management of radio-resistant and radiosensitive tumor cell lines in cobalt therapy for breast cancer.

Keywords: Radiation; MDA-MB-231; PBMC; LET; Dose; Dose rate.

Resu mo Objetivo: Neste estudo foi investigado o comportamento in vitro de linhagem de adenocarcinoma mamário (MDA-MB-231), radiorresistente, e de células mononucleadas do sangue periférico (PBMC) frente a diferentes doses de radiação, taxas de dose e cinética de tempo pós-irradiação, considerando o interesse para a radioterapia clínica.

Materiais e Métodos: As linhagens foram irradiadas com Co-60, com 2 e 10 Gy, em duas taxas de exposição distintas, 339,56 cGy. $\mathrm{min}^{-1}$ e um quarto da primeira, presentes em um período de 10 anos da cobaltoterapia, respectivamente. Coletas pós-irradiação foram realizadas em cinética pré-estabelecida de 24, 48 e 72 horas. Avaliou-se a resposta da densidade óptica em ensaio de viabilidade e foi feita uma análise morfológica.

Resultados: Células PBMC, sensíveis à radiação, apresentaram diminuição da viabilidade a 2 Gy e fortemente a 10 Gy em ambas as taxas de dose. Células MDA-MB-231 apresentaram diminuição da viabilidade apenas com dose e taxa de doses elevadas. Os resultados também demonstraram expansão clonal de MDA-MB-231 em baixa dose e taxa de dose pós 48-72 horas pós-irradiação.

Conclusão: Baixa taxa de dose apresenta possível impacto clínico de redução do controle tumoral de linhagens radiorresistentes em câncer de mama em cobaltoterapia.

Unitermos: Radiação; MDA-MB-231; PBMC; LET; Dose; Taxa de dose.

* Study developed at Department of Nuclear Engineering, Universidade Federal de Minas Gerais (UFMG), Belo Horizonte, MG, Brazil.

1. Postdoc, Associate Professor at Universidade Federal do Amazonas (UFAM), Manaus, AM, Brazil.

2. Master, Teacher at the private education network in Belo Horizonte, MG, Brazil.

3. Fellow Master degree in Veterinary Medicine, Universidade Federal de Minas Gerais (UFMG), Belo Horizonte, MG, Brazil.

4. Master, Fellow PhD degree in Nuclear Sciences and Techniques, School of Engineering, Universidade Federal de Minas Gerais (UFMG), Belo Horizonte, MG, Brazil.

5. Postdoc, Associate Professor at Universidade Federal de Minas Gerais (UFMG), Belo Horizonte, MG, Brazil.

Mailing Address: Dra. Patrícia Lima Falcão. Departamento de Técnicas Nucleares, Prédio PCA1, Engenharia - UFMG. Avenida Antônio Carlos, 6627, Pampulha. Belo Horizonte, MG, Brazil, 31270-901. E-mail: patricialfalcao@gmail.com.

\section{INTRODUCTION}

Carcinogenesis is a process where the physiological function of live cells is altered, resulting in abnormal and uncontrollable growth of a given organ or tissue ${ }^{(1)}$. The concept that cancer originates from uncontrolled cell division mechanisms is relatively recent. It is known that cell division is controlled by a network of signals acting in synergy, determining the exact moment of division, its frequency, and how the eventual errors can be repaired. Mutations in one

Received March 20, 2014. Accepted after revision November 10, 2014. 
or more segments of such a network may trigger abnormal neoplastic growth. However, it is unlikely that a single genetic change or a single agent could explain the onset of cancer.

Studies on breast cancer are characterized by enormous efforts as well as by considerable public and private expenditures. Studies regarding its causes have mostly been of an epidemiological character, with the support of experimental techniques of cellular and molecular biology ${ }^{(2,3)}$. Radiotherapy represents an integral part of the primary conservative treatment of breast carcinoma, aimed at achieving a better local tumor management ${ }^{(4,5)}$. The modern radiotherapy is aimed at achieving a favorable therapeutic index, leading malignant cells to lose their clonogenicity while preserving the functions of healthy tissues. The radiotherapy protocols utilized in the treatment of breast cancer include the exposure of the breast to two opposed tangential fields, in fractions of 1.8 to 2.0 Gy daily, five days a week, in multiple fractions until a total dose of 45 to $50 \mathrm{~Gy}$ is reached ${ }^{(6)}$. The utilized energy spectra comprise beams generated by 4 and 6 MV linear accelerators, or by Co-60. The Co-60 decays in beta emission into Ni-60, with a half-life of 5.2714 years, emitting gamma rays with energies of $1.17 \mathrm{MeV}$ and $1.33 \mathrm{MeV}^{(6)}$. After one decade, the dose rate is reduced to one fourth. Because of the difficulties encountered in the replacement of Co-60 sealed sources in cobalt therapy systems, one commonly finds radiotherapy centers whose cobalt therapy apparatuses have their activity and, consequently, their dose rate reduced due to the time of utilization of the apparatuses. In cobalt therapy, the prescribed treatment dose may be adjusted with the exposure time; however it is not possible to correct the dose rate during the treatment. It has already been reported in the literature that the survival of immortalized cancer cell lines changes not only with the dose kinetics, but also with the dose rate variation. It is a consensus among medical physicists that the variations in dose rate found in cobalt therapy over a ten-year period did not influence the treatment although, in radiobiological terms, changes in cell clonogenicity is observed as a function of the absorbed dose rate ${ }^{(6)}$.

Radiations may be classified according to the ionization density effects on a tissue volume. Gamma radiation is considered as being of the low linear energy transference (LET) type, i.e., it presents with sparse ionization density. The utilization of low LET radiation is a relevant tool in the treatment of cancer. The DNA repair mechanisms and consequential clonogenic capability recovery after low LET irradiation must be investigated in order to understand the results of clinical radiotherapy ${ }^{(7)}$.

Ionizing radiation utilized in breast radiotherapy causes several cell damages as it interacts with live tissues. The damages may be either appropriately repaired becoming innocuous, or inappropriately repaired, leading to mutations with possible carcinogenic effects. The damages may also be so severe that they lead to cell death ${ }^{(8)}$. A better understanding of the underlying DNA repair mechanisms after low and high
LET irradiation represents an investigation priority aimed at improving the results of clinical radiotherapy ${ }^{(9)}$. A great variety of biochemical cell systems are activated by ionizing radiation. It is likely that DNA lesions trigger an altered gene $\operatorname{expression}^{(10,11)}$. For example, changes in the cell cycle kinetics occur and cell cycle palsy or even apoptosis may be induced $^{(1,10)}$. The genetic and metabolic changes produced by ionizing radiation in cancer cells are complex and are yet to be better understood. As the understanding of radiation biological molecular effects increases, the capability to manipulate such process towards obtaining therapeutic advantages also increases, with the identification of specific molecular targets or alteration of exogenous agents such as dose, dose rate and selection of particles with different LETs ${ }^{(7)}$.

It is important to mention that the clinical response to radiotherapy is related to target cells radiosensitivity and resistance, which are associated with the clonogenic activity of the cell lines in study and their sensitivity to radiation ${ }^{(7,12)}$. The more undifferentiated and proliferative the tissue, the most sensitive it is to radiation, while on the other extreme, the more differentiated and stable the tissue, the more resistant it is. In such a context, erythroblasts and spermatogonia are more sensitive while muscle and nerve cells are more resistant. On the other hand, lymphocytes are non-clonogenic differentiated cells, being among the most radiosensitive cells in the body, because of their susceptibility to radiation-induced apoptosis ${ }^{(7)}$. In such a context, it is important to evaluate the variation of irradiated cancer cells clonogenic response in radiosensitive and radioresistant in vitro model, as a function of received radiation dose and dose rate, in the dominion interval of cobalt therapy. Thus, it is possible to verify the deleterious effects of ionizing radiation to assist in the determination of the radiotherapy to be applied.

The Ordinance No. 20 issued by Brazilian Health Surveillance Agency (Anvisa) regulates the operation of radiotherapy services, with a view on the patients', professionals' and general public health protection ${ }^{(13)}$. It establishes that telecobalt apparatuses with a dose rate $<50 \mathrm{cGy} \cdot \mathrm{min}^{-1} \mathrm{must}$ be put out of operation. Also, the installation of Co-60 sources with absorbed dose $<150 \mathrm{cGy} \cdot \mathrm{min}^{-1}$, in aqueous medium at a depth of $0.5 \mathrm{~cm}$, with source-to-surface distance equal to the source-isocenter distance, for a surface field of $10 \mathrm{~cm} \times 10 \mathrm{~cm}$ is also prohibited ${ }^{(13)}$. The investigation of the in vitro behavior of radioresistant and radiosensitive cell lines under different radiation doses and dose rates is pertinent, considering the interest for clinical radiotherapy, particularly when close to the acceptability ranges of the cobalt therapy apparatuses.

The present study was divided into two phases, considering the two types of cell lines. The first phase comprised experiments utilizing the in vitro cell culture model, with peripheral blood mononuclear cells (PBMC), which provided good efficiency in demonstrating the cell viability kinetics and monitoring of cell proliferation under different doses submitted to two radiation dose rates. Simultaneously, the 
experiments utilized breast cancer MDA-MB-231 cell lines, also under different radiation doses and two dose rates, with one corresponding to one-fourth of the other. The studies were supplemented with morphological analyses under optical microscopy of the irradiated and control cell lines.

\section{MATERIALS AND METHODS}

Pre-established cell lines and culture maintenance - PBMCs and MDA-MB-231 breast adenocarcinoma cell lines were utilized. The breast adenocarcinoma cell line presented with epithelial morphology derived from a metastatic site. The PBMCs were obtained from healthy volunteers. The cell cultures were maintained in RPMI-1640 culture medium supplemented with fetal bovine serum at $10 \%$ and gentami$\operatorname{cin}\left(50 \mu \mathrm{g} . \mu \mathrm{L}^{-1}\right)$ and streptomycin $\left(500 \mathrm{mg} \cdot \mathrm{mL}^{-1}\right)$ antibiotics, in T-25 culture vials in moist atmosphere containing 5\% of $\mathrm{CO}_{2}$ at $37^{\circ} \mathrm{C}$. The MDA-MB-231 cells grew confluent to the culture vial walls.

Separation of the PBMC cells - The patients' PBMCs were separated by following the procedure described by Gazzinelli et al. ${ }^{(14)}$. The heparinized blood was placed in 15 $\mathrm{mL}$ siliconized test tubes containing a mixture of one part of commercially obtained Ficoll-diatrizoate (Organon Teknika Corporation; Durham, NC) for two parts of blood submitted to centrifugation for 30 minutes at $1,400 \mathrm{rpm}$, at room temperature. After centrifugation a ring of mononuclear cells was obtained in the interface between the Ficoll and the plasma, which was carefully collected with the utilization of a Pasteur pipette, and transferred to $15 \mathrm{~mL}$ sterile conicalbottom test tubes (Falcon No. 2070). The volume was completed to $15 \mathrm{ml}$ with a RPMI-1640 (Gibco ${ }^{\circledR}$ ) unsupplemented solution, and the solution was again submitted to centrifugation (10 minutes, 1,200 rpm). The cells were washed for two more times (10 minutes, 1,200 rpm). After that, an aliquot of the cells suspension was collected and diluted (1:20) into an Eppendorf tube containing $90 \mu \mathrm{L}$ Turck solution, and the number of cells was determined by means of a Neubauer chamber with the aid of an optical microscope. The cell concentration was adjusted to a suspension containing $1.0 \times 10^{6}$ cells. $\mathrm{mL}^{-1}$ of supplemented RPMI-1640. The entire cell manipulation process was carried out in sterile conditions, in a laminar flow biological safety cabinet (Biological Cabinet BBL model 60474).

Control - Control was performed by means of non-irradiated PBMC and MDA-MB-231 cultures, maintained as above described.

Irradiation - The T-25 vials containing the cells were sealed with parafilm, and transported to the irradiation location inside a lidded rigid plastic container which was previously decontaminated with alcohol at $70 \%$. A $4 \mathrm{~cm}$ plate of equivalent tissue was placed beneath the T-25 vial, and the culture medium was filled to a depth of $5 \mathrm{~mm}$ in relation to the surface of adhered cells. Such a procedure was necessary in order to reach the electronic equilibrium and to ensure the prescribed dose on the confluent cells. The T-25 culture vials were submitted to Co-60 irradiation, in a Gammatron 580 radiotherapy apparatus. The field was 35 $\times 35 \mathrm{~cm}^{2}$, at room temperature. After exposure, the cells were returned to the $\mathrm{CO}_{2}$ incubator.

Dose kinetics - Doses of 2 and $10 \mathrm{~Gy}$ were utilized for peripheral blood mononuclear cells and for MDA-MB-231 cell line. The high value of $10 \mathrm{~Gy}$ was adopted in order to effectively observe clonogenic variations in the radioresistant MDA-MB-231 cell line within the time kinetics and dose rate.

Dose rate kinetics - Two different dose rates were utilized. The second corresponded to one fourth of the first one, obtained by approaching the sample to be irradiated to the Co-60 source. Thus, one sample was irradiated at a sourcesurface distance of $103 \mathrm{~cm}$, and the other at $51.5 \mathrm{~cm}$. Thus, one sample was irradiated with a source-surface distance of $103 \mathrm{~cm}$ while the other was irradiated at a source-surface distance of $51.5 \mathrm{~cm}$. The two distances were established in order to generate two different doses, as the beam intensity is reduced with the increase of the source-surface distance. Different exposure times define the required experimental dose. In cobalt therapy, the dose rates vary slightly on a daily basis. In the present case, the samples were irradiated at the same time, on the same day.

Sample collection - Aliquots of irradiated cell, homogenized and in suspension, from the PBMCs and MDA-MB231 samples were collected in triplicate from T-25 confluent vials. The triplicate $500 \mu \mathrm{L}$ aliquots were collected from the T-25 vials and transferred to Eppendorf tubes by means of an automatic pipette. The Eppendorf tubes were identified for the performance of the MTT test (3-(4.5 dimethylthiazol2yl) 2.5-diphenyltetrazolium bromide). A second set of samples was stored at $-20^{\circ} \mathrm{C}$ for further investigation of cytokine profiles/growth factors.

Kinetics along time - The in vitro culture vials which were submitted to the above mentioned doses and dose rates were returned to the $\mathrm{CO}_{2}$ incubator at $37^{\circ} \mathrm{C}$ after irradiation. Aliquots of both irradiated and non-irradiated cells (control) were collected at pre-established times, at 24, 48 and 72 hours after irradiation, respectively.

Viability evaluation - From the aliquots triplicates with different irradiation times, $100 \mu \mathrm{L}$ samples were added into each well of ELISA $(12 \times 8)$ flat bottom well plates and incubated for 24 hours. Then, $20 \mu \mathrm{L}\left(5 \mathrm{mg} \cdot \mathrm{mL}^{-1}\right)$ of MTT were added to each well and the samples were returned to the incubator where they were left metabolizing MTT for 4 hours. After metabolization, $80 \mu \mathrm{L}$ were discarded from each well, and $80 \mu \mathrm{L}$ of isopropanol $(0.04 \mathrm{M})$ were added. The plates were left in the incubator for additional 18 hours. The cell viability was evaluated by the measurement of optical density (OD), utilizing an enzyme-linked immunosorbent assay (ELISA) reader in the wave length of $595 \mathrm{~nm}$. The first row corresponds to white on the ELISA reader. The plates were read with the wave length of $595 \mathrm{~nm}$ at the ELISA ELx800 apparatus. The cell viability test by means of MTT has its principle on the viability verification and cell proliferation 
quantification based on the cleavage of the tetrazolium salt MTT. After incubation of the cells submitted to such an assay, a dye solution was formed, which was then measured by means of the ELISA reader, thus making it possible to correlate absorbance with the number of cells.

Statistical analysis - Intragroup comparison was performed, according to the two doses $(2$ and $10 \mathrm{~Gy})$ and two different dose rates for each one of the doses. The Student's $t$ test was utilized in order to obtain the mean value of the ODs obtained in the readings. Significance level of $5 \%$ was adopted. The SPSS for Windows 7 was utilized for the analyses ${ }^{(15)}$.

\section{RESULTS}

\section{PBMCs viability after Co-60 2 and $10 \mathrm{~Gy}$}

According to the calculations performed on the day of the samples irradiation, the utilized dose rates were: standard $339.56 \mathrm{cGy} \cdot \mathrm{min}^{-1}(\mathrm{X})$, and one fourth of the standard, corresponding to $84.89 \mathrm{cGy} \cdot \mathrm{min}^{-1}(\mathrm{X} / 4)$. A quantitative evaluation of cell viability was performed utilizing the radiosensitive and radioresistant cell lines, respectively, with the purpose of demonstrating that the viable cells after irradiation were capable of forming formazan crystals around them by the cleavage of the tetrazolium salt. After incubation of the cells submitted to this assay, a dye solution was formed, which was visualized at optical microscope, as shown on Figure 1.

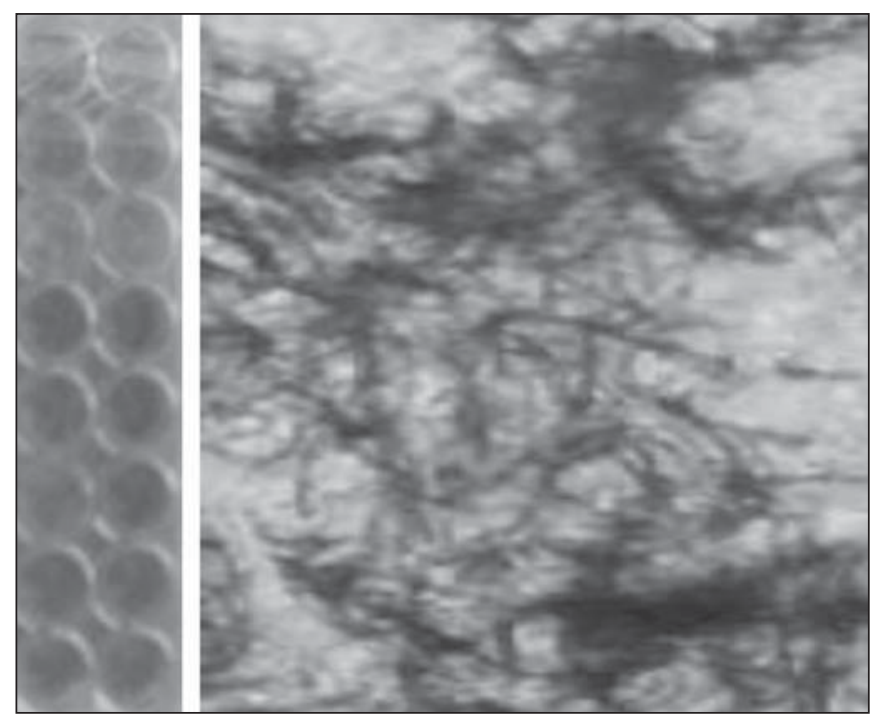

Figure 1. Photo of the cultures submitted to the MTT test, showing two rows of wells with development of formazan crystals, and image of one of the wells indicating the development of crystals superimposed to the non-viable cells.

2 Gy dose at standard rates and at one fourth of the standard - Figure 2 shows the cell viability curve evaluated at the MTT test for the in vitro PBMCs culture, with homogenized suspension of cells from PBMCs culture vials (T-25) which were irradiated with $2 \mathrm{~Gy}$ at the standard dose rate of 339.56 $\mathrm{cGy} \cdot \mathrm{min}^{-1}$ and of $84.89 \mathrm{cGy} \cdot \mathrm{min}^{-1}$. The data show a statistically significant decrease $(p<0.05)$ in the OD at the dose of $2 \mathrm{~Gy}$ in relation to the control at all studied times. Similar behavior in the cell line survival decrease at the 24-hours time for both dose rates can also be observed. It is interesting to notice that at the pre-established times, the increased cell proliferation was observed in the control (non-irradiated cells), which might be a consequence of the physiological process of cell replication (mitosis). However, at the 48-hours time, as the cell viability at the standard dose rate and at one fourth of that is compared, it is suggested that, with the radiosensitive cell line, the radiation dose rate effects can already be observed due to the change in viability, showing that the decrease in dose rate induces a greater viability. The same effect can be observed at the 72-hour time, not as clearly though.

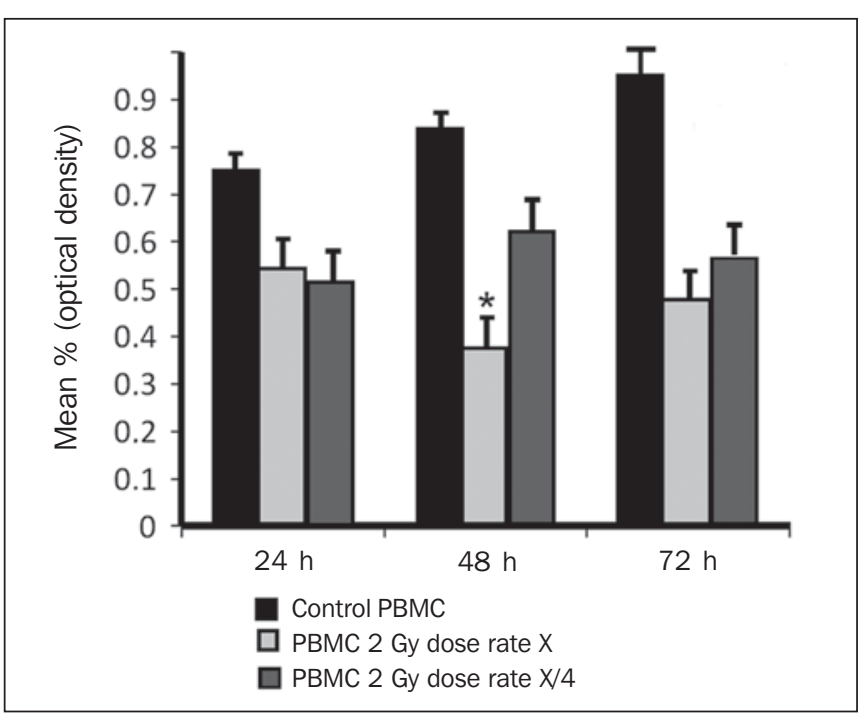

Figure 2. Survival curve determined by the MTT test, before and after in vitro PBMC culture exposure with the dose of $2 \mathrm{~Gy}$. The black bar represents the control of non-irradiated cells and the light gray bar represents the culture irradiated with $2 \mathrm{~Gy}$. The cells were irradiated with the dose rate $X=339.56 \mathrm{cGy} / \mathrm{min}$ and $\mathrm{X} / 4$. The bars express the mean of triplicates and the standard deviation for PBMC cultures irradiated with the dose of 2 Gy and also for the respective control (nonirradiated cell lines). The signal * represents statistically significant difference in relation to the bars without ${ }^{*}$. $(p<0.05)$.

$10 \mathrm{~Gy}$ dose at standard rates and at one fourth of the standard - The decrease in cell viability was extremely significant $(p<0.05)$ at the 24-, 48- and 72-hour time, not only in relation to the non-irradiated control, but also in an equivalent manner for the two dose rates, as shown on Figure 3. The mean OD percentage was reduced to $7 \%$ and $15 \%$, particularly at the 72-hour time, suggesting that the high dose potentializes cell death in the culture, tending to cell viability irreversibility when the dose was applied at a rate of 339.56 cGy. $\mathrm{min}^{-1}$. However, at the one fourth dose rate, in spite of the OD reduction, a reversibility effect can be observed in the cell viability decrease at the 48 -hour and even at the 72hour time.

\section{MDA-MB-23 1 cell line viability after Co-60 2 and $10 \mathrm{~Gy}$}

Dose of 2 Gy at standard rates and at one fourth of the standard rate - Evaluation of cell viability by MTT testing of in vitro MDA-MB-231 cells suspensions irradiated with $2 \mathrm{~Gy}$ at the $339.56 \mathrm{cGy} \cdot \mathrm{min}^{-1}$ dose rate and at one fourth of 


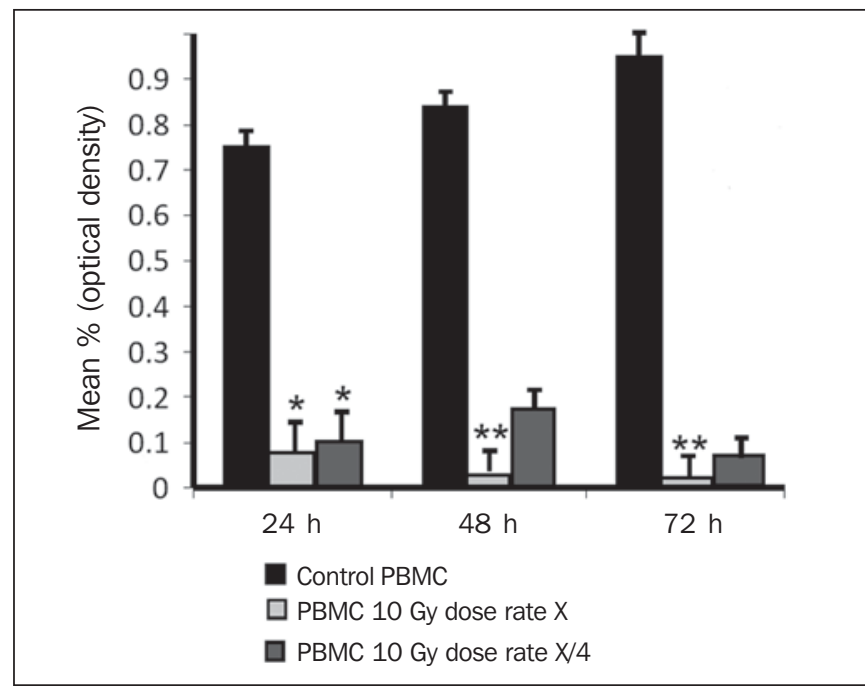

Figure 3. Survival curve determined by the MTT test, before and after in vitro exposure of a healthy individual's PBMC culture at the dose of $10 \mathrm{~Gy}$. The black bar represents the control of non-irradiated cells, and the light gray bar represents the culture irradiated with $10 \mathrm{~Gy}$. The cells were irradiated with the dose rate of $\mathrm{X}=$ $339.56 \mathrm{cGy} / \mathrm{min}$ and $\mathrm{X} / 4$. The bars express the mean of triplicates and the standard deviation for PBMC cultures that were irradiated with the dose of 10 Gy and also for the respective control (non-irradiated). The signal * represents statistically significant difference only in relation to the bar without * $(p<0.05)$; while ** represents statistically significant difference in relation to neighboring bars without *

the standard rate, as shown on Figure 4. The control experiment demonstrated the capability of the MDA-MB-231 cells to fill the T-25 vial and maintain the clonogenicity beyond the $48 \mathrm{~h}$ post confluence without exchanging the culture medium, as one observes on the control viability curve (Figure 4). The control experiment also demonstrated that after 72 hours the cell concentration is high and cell density leads to a high consumption of nutrients from the supplemented medium, making it acid on account of the excreted waste products over the 70-120-hour period, under the conditions of no medium exchange. As a low radiation dose is considered, the observed results in this assay were opposed to the observations made for the PBMCs in culture, under the same exposure conditions and correlated doses. Besides not pointing towards decrease in cellular viability after irradiation with 2 Gy, the data actually demonstrated an enhancement of such viability, suggesting a clonal expansion at such dose, particularly after 48 hours in culture. The same observations were made for the $2 \mathrm{~Gy}$ dose at one fourth of the dose rate, also suggesting a radioresistance when the dose was reduced (Figure 4). It is possible to observe that the dose rate reduction did not significantly impact the survival after 24 hours, but became impacted the viability at 48 and 72 hours, with the lower rate leading to an increase in cell survival along time.

Dose of 10 Gy at standard rates and at one fourth of the standard - Figure 5 shows a significant decrease $(p<0.05)$ in cell viability when the cells suspension received a dose of $10 \mathrm{~Gy}$, measured 24 hours after the exposure at the rate of $339.56 \mathrm{cGy} \cdot \mathrm{min}^{-1}$ in relation to the non irradiated control. The decrease in cell viability at such a dose increasingly followed the time kinetics in contrast to the effect observed

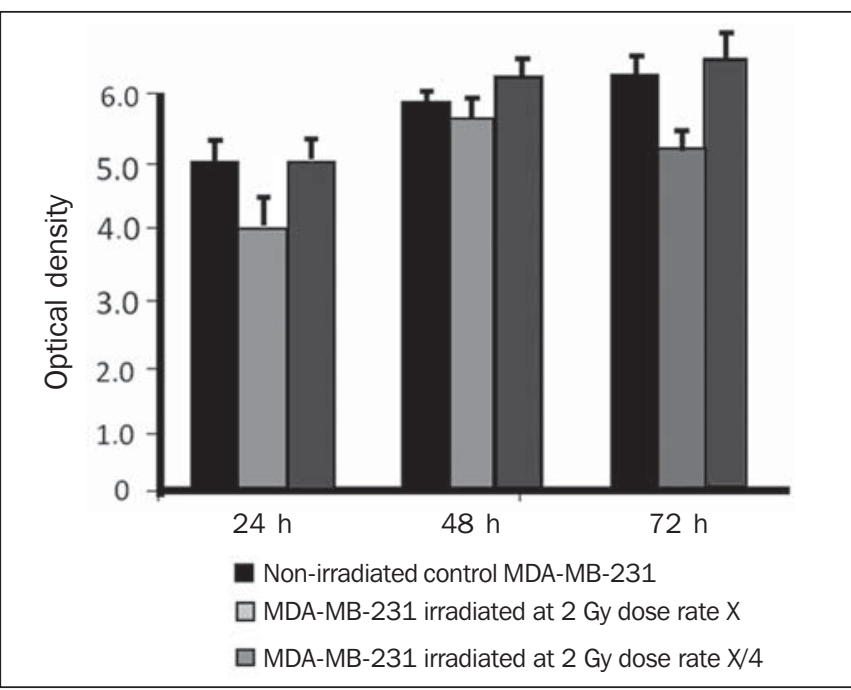

Figure 4. Survival curve determined by the MTT test, before and after in vitro exposure of MDA-MB-231 cell culture at the dose of 2 Gy. The black bar represents the control of non-irradiated cells, and the light gray bar represents the culture irradiated with 2 Gy, with the dose rate of $X=339.56 \mathrm{cGy} / \mathrm{min}$ and $X / 4$. The bars express the mean of triplicates and the standard deviation for MDA-MB231 cell cultures, irradiated at the dose of 2 Gy and also for the respective control (non-irradiated). The signal * represents statistically significant difference in relation to the bars without * $(p<0.05)$.

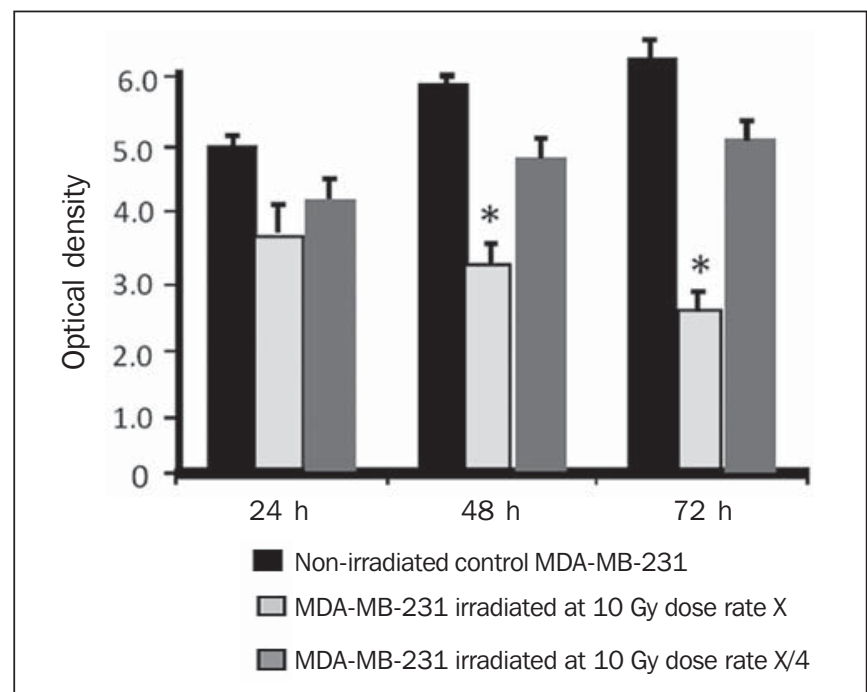

Figure 5. Survival curve determined by the MTT test, before and after in vitro MDA-MB-231 cells culture exposure at the dose of 10 Gy. The black bar represents the control with non-irradiated cells and the light gray bar represents the culture irradiated with $10 \mathrm{~Gy}$, with the dose rate $X=339.56 \mathrm{cGy} / \mathrm{min}$ and $X / 4$. The bars express the mean of triplicates and the standard deviation for MDA-MB231 cell cultures irradiated at the dose of $10 \mathrm{~Gy}$ and also for the respective control (non-irradiated). The signal * represents statistically significant difference in relation to the bars without * $(p<0.05)$.

when the cells suspension received the dose of $2 \mathrm{~Gy}$ at the same rate. Equally to the radiosensitive cells, the behavior of the MDA-MB-231 radioresistant clones shows viability recovery at the reduced rate, while at the standard rate such a recovery is not perceptible.

\section{Morphology of irradiated cell lines}

Figure 6 shows non-irradiated MDA-MB-231 cells obtained from the control vial, besides irradiated MDA-MB- 
Figure 6. Non-irradiated MDA-MB231 cells morphology previously to the experiment, and post-irradiated at $10 \mathrm{~Gy}$, in a field where apoptotic bodies and still viable cells are seen.

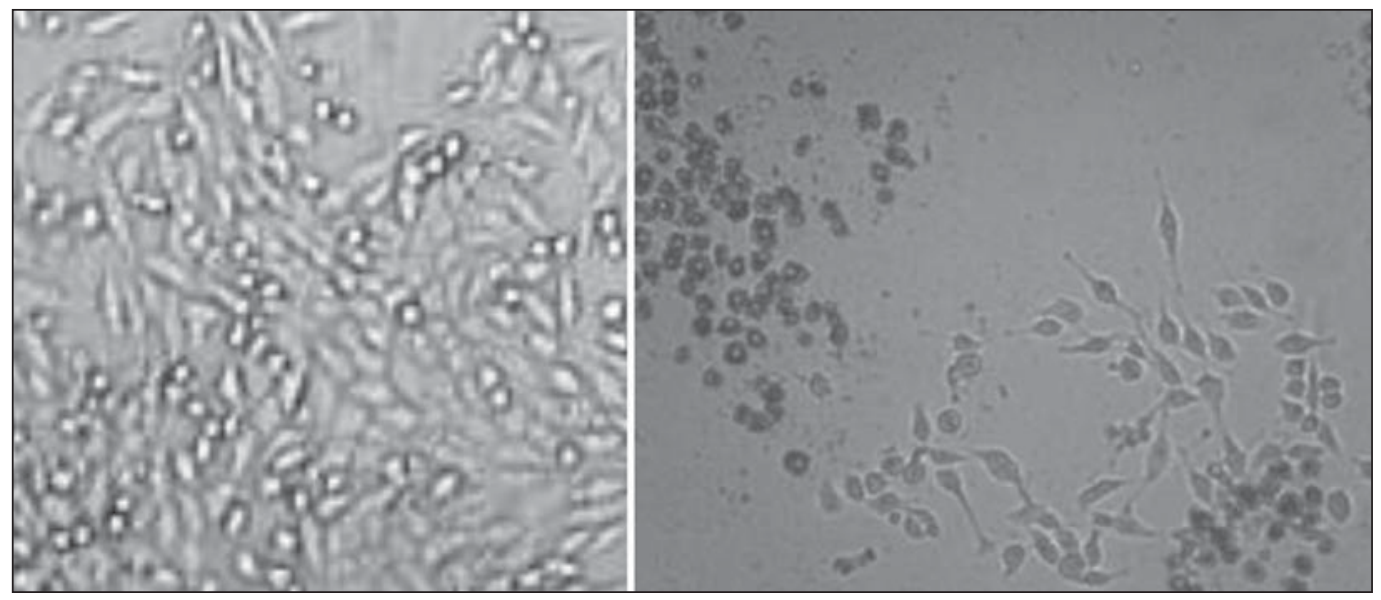

231 culture wells at different exposure times. The apoptotic cells present with a differentiated morphology with respect to size and granularity, being much more granular than the cells which were not damaged by radiation. There are signs of the presence of vacuoles and apoptotic bodies. There is also the presence of dysmorphic cells with possible indication of necrosis. It is interesting to notice that the morphological features of breast adenocarcinoma MDA-MB-231 cell line had already been previously approached in another study, suggesting deleterious effects at higher doses (10 Gy). Studies developed by Campos et al. ${ }^{(16)}$, which corroborate the findings of the present study, show the analysis of images of vials with MDA-MB-231 cell line during irradiation and suggested the presence of apoptotic processes.

\section{DISCUSSION}

The present study demonstrated that the viability of radioresistant breast adenocarcinoma MDA-MB-231 cell line and radiosensitive PBMC line were significantly influenced by dose, dose rate and by the post-experiment time kinetics. The effect of dose rate could be recognized by the viability analysis at the intermediate times of 48 and 72 hours after exposure to radiation. The decrease in cell viability with the dose confirms the findings reported by Cockerham et al. ${ }^{(17)}$, who suggested that the toxic effects of radiation on cell lines depend upon the total absorbed dose. Although it is obvious that the effect of the dose itself was considered to have an impact on the induction of cell death, probably leading to an imbalance between cell proliferation and apoptosis, the influence of such process with variations of the dose rate in kinetics of post-irradiation time can also be observed and considered as being relevant.

In the present study, cells which presented radiosensitive pattern were irradiated at doses ( 2 and $10 \mathrm{~Gy})$ that potentially interfered with the clonogenicity of those cell lines. The PBMCs are involved in the immune response to the treatment itself, and is intimately associated with the patient's response capability. One can also infer that the dose rate played a significant role in such a context. In the case of the irradiated PBMCs, it is possible to suggest that the change observed in the decrease of proliferation after the $2 \mathrm{~Gy}$ dose could be attributed to the possible role played by ionizing radiation, triggering biomolecular changes that very likely activate the phosphorylation of kinases responsible for the apoptosis cascade in the radiosensitive cell line ${ }^{(9)}$, and that such an effect could already be observed even at a low dose, when compared with the observed doses of 2 and $10 \mathrm{~Gy}$. At the dose of $2 \mathrm{~Gy}$, the effect of application diluted in time appears recognizable if one compares the mean percentages of OD for PBMCs. The decrease in the viability curve was much less perceptible with the rate reduced to one fourth of the standard, at the 24-, 48- and 72-hour times, although a difference has been observed in the non-irradiated control. There is a relevant impact of such time on the recovery of the cells, on the induction of the physiological cell replication process and/or on the cell mutagenesis. Additionally, a decrease in cell viability was observed (although not significant), reflected by the mean OD percentage at the first 24 hours, when the cells culture was also irradiated with intermediate doses (data not shown). Such a decrease was significant in the following 48 hours in relation to the 24-hour time, suggesting that the vital functions of PBMCs already seems to have been affected after exposure to that dose.

As counterpart to the study with radiosensitive cells, the viability of a radioresistant MDA-MB-231 breast adenocarcinoma cell line shows a different behavior. Even with the $10 \mathrm{~Gy}$ dose, one could observe that a rate reduced to one fourth of the standard, increased the MDA-MB-231 cell line recovery potential from 48 hours after irradiation. Experimental model studies have demonstrated that MDA-MB-231, MDAMB435S and U25 1 cell lines present with a differentiated biomolecular profile as therapeutically treated and untreated, showing high mRNA and protein expression. In the study developed by De Bacco et al. ${ }^{(18)}$, protein expression and signal transduction were compared in irradiated and in nonirradiated cells. The cell invasiveness was associated with noninhibition of siRNA (RNA silencing) PHA665752 or JNJ38877605 kinase and also in viability and clonogenesis assays ${ }^{(19)}$. Cell lines such as MDA-MB-231 become a target of breast cancer radiotherapy. According to an experimental 
model study, ineffective radiation doses or dose rates could define the destiny of malignant cell lines such as MDA-MB231 in response to cobalt therapy.

Several factors may influence radiobiological effects, such as quality of the ionizing energy, radiation intensity (reversible or irreversible effect), exposure mode - i.e. exposure of the entire body or only part of it, either external or internal exposure, unique fraction, continued or fractioned exposure -, exposure time and dose distribution among the several tissues. The effect of increasing dose diluted in time with the rate reduced to one fourth of the standard, suggested that the physiological process of replication was influenced by the exposure time, since it seems there was a significant recovery of the OD percentage. Therefore, it is suggested that the dose rate seems to play an important role in the way that such damages are potentialized in the cell and, possibly, that the very induction of cell death kinetics might be triggered by means of alternative signaling as a function of administered doses.

On the other hand, as a same dose was administered to the culture with a longer time interval, and the rate reduced to one fourth of the standard dose, it was possible to observe that the effect on the survival curve was better recognizable after 48 hours, as the 2 Gy dose is considered. However, it is important to highlight that at 72 hours one could observe a significant decrease $(p<0.05)$ in cell viability. It is important to remind that the effect of fractioned radiation doses had already been demonstrated by Soto et al. ${ }^{(19)}$ who utilized a breast cancer cell line with intermediate resistance, evaluating the proliferation of fibroblasts submitted to much lower doses than those utilized in the present study.

It is important to highlight that the dose corresponds the total amount of energy absorbed by a mass unit, while the dose rate reflects the kinetics of how the dose is absorbed over time. On its turn, the third parameter given by the postirradiation time kinetics reflects the repair and repopulation ability of the in vitro cell line. In radiobiology, both the dose and the dose rate have a crucial importance, i.e. high doses may have subtle effects as applied at extremely diluted rates, in the same manner that reduced doses may have marked effects if applied at high dose rates, in very short time spans $^{(8)}$. In truth, the dose rate reflects the manner in which sub-lethal damages are distributed and repaired along time.

A pioneering in vitro experimental model study developed by Kaplan et al. ${ }^{(20)}$ demonstrated that ionizing radiation can cause a paradoxical pro-metastatic effect. Such an effect was observed after doses considered as being insufficient to induce malignant cells death in the primary tumor in experiments with animals, and rarely after curative radiation therapy. Recent studies have indicated that ionizing radiation can promote a positive selection of pre-existing, intrinsically radio-resistant tumor, suggesting an attractive mechanistic explanation for the tumor progression induced by radiation ${ }^{(7,18,21,22)}$. However, there are also evidences that radiation is capable of inducing an adaptive phenotype intended to tissues regeneration, which might support the metastatic behavior $^{(17,19)}$. Such a phenotype change may be understood as a response to stress generated by radiation and by the attempt to repair damages to $\mathrm{DNA}^{(23)}$. In individual cells, damages to DNA induce specific molecular mechanisms, mainly orchestrated by ataxia telangiectasia mutated, ataxiap53, which are capable of blocking the DNA replication and repair ${ }^{(23,24)}$. If such repair fails, a normal cell is programmed to execute apoptosis or undergo proliferative suppression by the senescence process. However, after the death of radiation damaged cells, the tissues must reestablish their appropriate standard number of cells as a function of regeneration and/or cicatrization by the surviving normal or neoplastic cells.

A higher dose (10 Gy) may have produced an impact on the enzyme pathways that lead cells into apoptosis at a faster time kinetics, which reflects the low OD observed at the three collection times $(24,48$, and 72 hours), with TNF- $\alpha$ start and presence of reactive oxygen species (ROS $)^{(11,25)}$. Although it became clear that the dose effect itself was considered as impacting on the induction of cell death, leading to an imbalance between proliferation and apoptosis, it would be interesting, at a later moment, to mark the receptors of such radiosensitive cell line for apoptosis, in accordance with De Bacco et al. ${ }^{(18)}$.

Radiotherapy leads patients to a favorable therapeutic index, leading to loss of tumor clogenicity, while preserving as much as possible the normal adjacent tissues ${ }^{(26)}$. Thus, radiotherapy should be successfully utilized for the local treatment of primary cancer ${ }^{(19)}$. However, some tumor cell lines submitted to treatment become potentially more aggressive, leading to disease recurrence. In such a context, one of the arguments raised is related to the treatment planning and its efficiency, considering the effect of dose rate in cobalt therapy, as Co-60 has a half-life of 5 years and, after two half-lives (10 years), the activity reaches one fourth of the initial activity and, consequently, radiotherapy applied at the same dose will have a dose rate reduced to one fourth. Such a situation is present at radiotherapy centers and, consequently, with a view on the radiobiological results of the present study, one can confirm that cobalt therapy will be influenced by the decay time of the primary source, even if the ionization amount is adjusted. The experimental findings on viability and repopulation of the studied cell lines at a 72-hour time for reduced dose rates of $85 \mathrm{cGy} \cdot \mathrm{min}^{-1} \mathrm{dem}$ onstrate the importance of complying with the RDC-20 standard established by Anvisa, which limits the utilization of Co-60 sources at dose rates below $50 \mathrm{cGy} \cdot \mathrm{min}^{-1}$.

\section{CONCLUSION}

Peripheral blood mononuclear cells irradiated at doses of 2 and $10 \mathrm{~Gy}$, regardless of dose rate, presented decreased viability. Breast cancer cells, which are less radiosensitive, presented decreased viability only after irradiation with high dose rate and dose of $10 \mathrm{~Gy}$. Such findings can impact radio- 
therapy and influence the treatment quality. As regards postradiation time kinetics, radiosensitive and radioresistant cell lines at two dose rates demonstrated enhancement of viability of radiosensitive (PBMC) and radioresistant (MDA-MB231) clones after 48-72 hours with decreased dose rate in the period of two Co-60 half-lives, with possible clinical impact leading to decreased tumor management in cobalt therapy.

\section{REFERENCES}

1. Pollock RE, Doroshow JH, Khayat D, et al. UICC Manual de oncologia clínica. $8^{\mathrm{a}}$ ed. São Paulo, SP: John Wiley, Fundação Oncocentro de São Paulo; 2006.

2. Fentiman I. Diagnóstico e tratamento do câncer inicial de mama. Porto Alegre, RS: Artes Médicas; 1993.

3. Santos CER, Mello ELR. Manual de cirurgia oncológica. $2^{\mathrm{a}}$ ed. São Paulo, SP: Tecmedd; 2008.

4. Veronesi U, Luini A, Andreoli C. A conservação da mama: indicações e técnicas da quadrantectomia, dissecção e radioterapia no câncer de mama. São Paulo, SP: Editora Ícone; 1992.

5. Liu Y, Appleyard MV, Coates PJ, et al. p53 and gamma radiation in the normal breast. Int J Radiat Biol. 2009;85:1026-31.

6. Khan FM. The physics of radiation therapy. 4th ed. Baltimore, MD: Lippincott Williams \& Wilkins; 2010.

7. Hall EJ, Giaccia AJ. Radiobiology for the radiologist. 7th ed. Philadelphia, PA: Lippincott Williams \& Wilkins; 2011.

8. Murad AM, Katz A. Oncologia: bases clínicas do tratamento. Rio de Janeiro, RJ: Guanabara Koogan; 1996.

9. Vandersickel V, Mancini M, Slabbert J, et al. The radiosensitizing effect of Ku70/80 knockdown in MCF10a cells irradiated with Xrays and $\mathrm{p}(66)+\mathrm{Be}(40)$ neutrons. Radiat Oncol. 2010;5:30.

10. Toledo JM, Siqueira SL, Campos TPR, et al. Phenotypic behavior of PBMCs from irradiated dogs based on flow cytometry. J Biol Regul Homeost Agents. 2013;27:309-17.

11. Falcão PL, Cuperschmid EM, Trindade BM, et al. Transforming growth factor- $\beta$ and matrix metalloproteinase secretion in cell culture from ex-vivo pbmc after exposure to uv radiation. J Biol Regul Homeost Agents. 2014;28:333-40.

12. Andrade LM, Leite MF, Goes A, et al. Cellular viability and apoptosis of human breast cancer MDAMB-231 cell line after Co-60 irradiation. Acta Microsc. 2003;12:43-8.

13. Brasil. Ministério da Saúde. Agência Nacional de Vigilância Sanitária. Resolução no 20 de 02/02/2006 / ANVISA - Agência Nacional de Vigilância Sanitária (D.O.U. 06/02/2006). [acessado em $1^{\circ}$ de setembro de 2014]. Disponível em: www.diariodasleis.com.br/ busca/exibelink.php?numlink=1-9-34-2006-02-02-20.

14. Gazzinelli G, Katz N, Rocha RS, et al. Immune responses during human schistosomiasis mansoni. X. Production and standardization of an antigen-induced mitogenic activity by peripheral blood mononuclear cells from treated, but not active cases of schistosomiasis. J Immunol. 1983;130:2891-5.

15. IBM Software. SPSS software. [acessado em $1^{\circ}$ de setembro de 2014]. Disponível em: http://www-01.ibm.com/software/analytics/ spss.

16. Campos TPR, Valença PLF, Cuperschmid EM, et al. Efeito das radiações emitidas por sementes de hólmio-166 de baixa atividade em cultivo celular MDAMB231. In: COLAOB 2010 - $6^{\circ}$ Congresso Latino Americano de Órgãos Artificiais; 2010, Gramado, RS. Anais do COLAOB. 2010; 1:1-7.

17. Cockerham KP, Kennerdell JS. Does radiotherapy have a role in the management of thyroid orbitopathy? View 1. Br J Ophthalmol. 2002;86:102-4.

18. De Bacco F, Luraghi P, Medico E, et al. Induction of MET by ionizing radiation and its role in radioresistance and invasive growth of cancer. J Natl Cancer Inst. 2011;103:645-61.

19. Soto J, Quindós LS, Cos S, et al. Influence of low doses of radiation due to ${ }^{222} \mathrm{Rn}$ on proliferation of fibroblasts and MCF-7 human breast cancer cells in vitro. Sci Total Eviron. 1996;181:181-5.

20. Kaplan HS, Murphy ED. The effect of local roentgen irradiation on the biological behavior of a transplantable mouse carcinoma; increased frequency of pulmonary metastasis. J Natl Cancer Inst. 1949;9:407-13.

21. Bernier J, Hall EJ, Giaccia A. Radiation oncology: a century of achievements. Nat Rev Cancer. 2004;4:737-47.

22. Huber SM, Butz L, Stegen B, et al. Ionizing radiation, ion transports, and radioresistance of cancer cells. Front Physiol. 2013;4: 212 .

23. Von Essen CF. Radiation enhancement of metastasis: a review. Clin Exp Metastasis. 1991;9:77-104.

24. Lövey J, Fazekas K, Ladányi A, et al. Low-dose irradiation and shortexposure suboptimal-dose paclitaxel adversely modulate metastatic potential of squamous carcinoma cells. Strahlenther Onkol. 2003; 179:812-8.

25. Harada H. How can we overcome tumor hypoxia in radiation therapy? J Radiat Res. 2011;52:545-56.

26. Tamamoto T, Ohnishi K, Takahashi A, et al. Correlation between gamma-ray-induced G2 arrest and radioresistance in two human cancer cells. Int J Radiat Oncol Biol Phys. 1999;44:905-9. 